\title{
Evaluation of Standardized Extract of Centella Asiatica on Cell Viability and Repressive Cancer Migration in Metastatic Colorectal Cancer Cells in Vitro
}

\author{
Suwisit MANMUAN ${ }^{1, *}$, Ponwit MANMUAN ${ }^{2}$, \\ Punyo YOYKAEW ${ }^{3}$, Piyachat THUETONG ${ }^{3}$, Patchraporn ASIPONG ${ }^{3}$, \\ Nattanicha RIANTONG ${ }^{3}$ and Mayuree H. TANTISIRA ${ }^{1}$ \\ ${ }^{I}$ Division of Pharmacology, Faculty of Pharmaceutical Sciences, Burapha University, \\ Chonburi 20131, Thailand \\ ${ }^{2}$ Department of Intellectual Property, Ministry of Commerce, Nonthaburi 11000, Thailand \\ ${ }^{3}$ Division of Pharmacy, Faculty of Pharmaceutical Sciences, Burapha University, \\ Chonburi 20131, Thailand
}

("Corresponding author's e-mail: suwisit@buu.ac.th)

Received: 8 October 2019, Revised: 5 March 2020, Accepted: 5 April 2020

\begin{abstract}
Centella Asiatica has been traditionally used as herbal medicine to treat various disorders, such as ulcers and psoriatic disease. ECa233 is an herbal extract of Centella Asiatica containing madecassoside $(46.3 \%)$ and asiaticoside (41.6\%) that shows a highly acceptable safety profile appropriate for drug development and use as an herbal drug for humans. 5-fluorouracil (5-FU) is a chemotherapeutic agent generally known as the first-line chemotherapy for colorectal cancer. Representative combined chemotherapy with 5-FU, namely the FOLFOX regimen (5-FU, leucovorin, oxaliplatin), has been widely used in hospitals and is typically selected as a chemotherapeutic regimen in prescriptions. However, the unresolved problems appearing in clinical situations are the refusal to accept the chemotherapy leading to drug resistance and the severe side effects after being administered intravenously to the entire body. Therefore, the discovery of a novel pure standard agent to enhance the efficacy of 5-FU and overcome this drug resistance still needs to be explored. To assess the pharmacological activity and safety profile of ECa233 is a major goal in cancer drug discovery. ECa233 was evaluated for its anti-cancer, antimigration, anti-invasive activities and was explored regarding the safety data on normal cells. The results demonstrated that ECa233 effectively inhibited the cell viability, colony forming, and truly inactivated cell migration/invasion through repressive the MMP-9 invasive factor. Pharmacological interaction with 5-FU was synergism in cancer cells and highly safe to normal cell growth. The results suggest that ECa233 could be used as a combinative drug therapy with standard chemotherapy treatment and other medicinal drugs such as a targeted therapy to treat colorectal cancer patients.
\end{abstract}

Keywords: Cell survival, Colorectal cancer, ECa233, 5-Fluorouracil, Synergism

\section{Introduction}

Colorectal Cancer (CRC) is the fourth leading cause of cancer-associated deaths and the incidence rates in Thailand are rapidly increasing [1]. The curative approach in the response to colorectal cancer follows various guidelines [2]. Surgical techniques are frequently used in various clinical situations, while chemotherapy is primarily the principal curative agent that kills the tumor cells and regularly plays an important role in treating patients with CRC [3]. Particularly, advanced CRC patients are usually highly at risk to morbidity/mortality after being treated with medicine. 5-fluorouracil (5-FU) is a general class of 
chemotherapeutic drugs that have been extensively used as the first-line chemotherapeutic regimen in the past several decades [4,5]. The toxicity of this chemotherapeutic agent 5-FU, such as myelosuppression, stomatitis, nausea, vomiting, and hand-foot syndrome, is a major obstacle to success in cancer chemotherapeutic treatment. However, the combination with newer chemotherapeutic drugs such as oxalipatin and irinotecan improved the response rates to $40-50 \%$ and also reduced unwanted side effects that were generated from employing multiple drug therapeutic use [6,7]. These findings suggest that 5-FU has a favorable safety profile and is suitable for drug combination treatment. The problems of currently available molecular targeted therapies that are generated in personalized cancer therapy are the adverse events and high costs for treatment. Therefore, it is essential to use new therapeutic modalities for enhancing oncologic health care and to be fully aware of the adverse side effects [8]. The inadequacy of single medication therapy can be circumvented by using combinative anti-neoplastic agents. Therefore, the improvement of cancer therapy by searching for newer chemo-sensitizing agents is urgently required. The discovery of natural herbal chemopreventive medicine in combination treatment will not only enhance the effectiveness of the chemotherapy but can also reduce the side effects of chemotherapeutic drugs [9]. The advantages of combination therapy are the synergistic or additive results, a reduction in the chemotherapeutic dose resulting in diminished adverse toxicity, patient compliance and delayed multipledrug resistance that generally occurs in advanced colorectal cancer patients [10]. The results from reducing the doses of chemotherapy lead to the reduction of toxicity and improved patient tolerability. The optimization of combination therapy results in pharmacodynamic synergism when the combined effect is greater than that of the individual drug. The target sites of each drug that are located in the different sites or different pathways will be potentially greater than those of the individual drug $[11,12]$. Natural products are the source of agents used to reduce drug resistance and may have benefits in cancer drug development. Vincristine and vinorelbine were derived from natural products and are beneficial as anti-cancer agents $[13,14]$. The use of natural products is not only beneficial as medicine for cancer treatmentbut also to avoid the adverse side effects occurring during chemotherapeutic treatment. Based on the above standpoint, it is essential to find a natural chemotherapeutic regimen that can act against aggressive cancer progression.

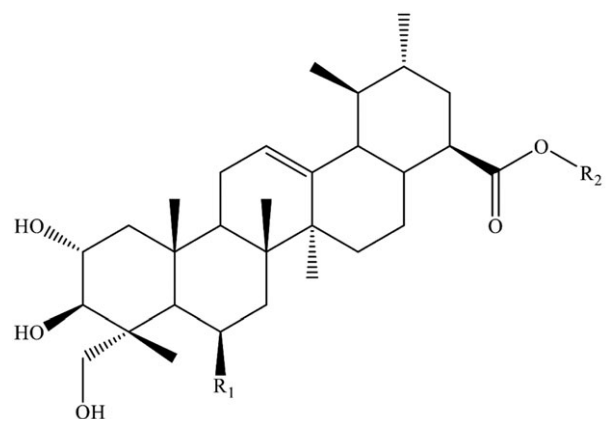

$$
\begin{array}{lll}
\text { Asiaticoside } & \mathrm{R}_{1}=\mathrm{H} & \mathrm{R}_{2}=\mathrm{Glu}-\mathrm{Glu}-\mathrm{Rha} \\
\text { Madecassoside } & \mathrm{R}_{1}=\mathrm{OH} & \mathrm{R}_{2}=\mathrm{Glu}-\mathrm{Glu}-\mathrm{Rha} \\
\text { Asiatic acid } & \mathrm{R}_{1}=\mathrm{H} & \mathrm{R}_{2}=\mathrm{H} \\
\text { Madecassic acid } & \mathrm{R}_{1}=\mathrm{OH} & \mathrm{R}_{2}=\mathrm{H}
\end{array}
$$

Figure 1 Chemical structure of triterpenes from Centella Asiatica (Glu: glucose, Rha: rhamnose) (Source of chemical structure: Hengjumrut, 2018 [22]).

Centella Asiatica, known as "Bao-bog" in Thailand, has been traditionally used as herbal medicine in Asian countries. ECa233 is an active ingredient that is found in Centella Asiatica, which has been welldefined as a white to an off-white powder containing triterpenoid glycosides not less than $80 \%$ in the ratio between madecassoside and asiaticoside $(1.5 \pm 0.5)$ [15]. The chemical structures of madecassoside and asiaticoside are highly similar but differentiated by the hydroxyl group at C6 (Figure 1). Monitoring in recent years has clearly defined the beneficial well-characterized properties of ECa233 and proven it to be a promising candidate for various type of diseases. It has been shown to possess diverse pharmacological activities. The biological activities of Centella asiatica and ECa233 have been described, including 
http://wjst.wu.ac.th

wound healing activity when topically applied to second-degree burns in rats [16], inducing anxiolyticlike effects in acutely stressed animals [17], providing ameliorating effects on memory impairment in the brain [18], and modulation of neuronal activity and neuroprotective effects resulting from rotenoneinduced Parkinsonism in rats [19,20].

Toxicity studies of ECa233 have indicated that the standardized extract of ECa233 does not show toxicity after oral administration of up to $10 \mathrm{~g} / \mathrm{kg}$ in rats or mice [21]. Following the intravenous administration of madecassoside and asiaticoside through the lateral tail vein in Wistar rats, drug monitoring after euthanasia and collection of tissue samples demonstrated that approximately $80-90 \%$ of the dose of the drugs received is exactly distributed in several organs. Moreover, after complete administration of ECa233, the animals exhibited good tolerability to this compound. The serums aspartate transaminase (AST) and alanine transaminase (ALT) were not changed in the blood level after administration, indicating non-liver damage toxicity after $24 \mathrm{~h}$ post-receiving dose. The toxicity and physiological changes were not observed and blood creatinine levels were not altered from the normal rats, indicating that toxicity to kidneys did not occur after administration [22]. The disposition kinetics of ECa233 after administration were assessed by liquid chromatography-tandem mass spectrometry, which showed that madecassoside and asiaticoside were rapidly absorbed and distributed to the brain, stomach, and skin within $1 \mathrm{~h}$. ECa233 is mainly excreted as an unchanged form after injection, and triterpenic acid metabolites were mainly excreted via feces after oral administration of ECa233 [23]. To explore the safety and tolerability of standardized extract of ECa233, oral doses of ECa233 were given to healthy Thai volunteers $(250$ and $500 \mathrm{mg}$ ). The volunteers tolerated the ECa233 well and did not discontinue the study due to serious adverse effects [24]. The extensive data on ECa233 is favorable in terms of the safety profile and thus, warrants the main interest in this beneficial extract for human use. The pharmacokinetics and metabolism of these extracts are very interesting if they are implemented in traditional herbal use with various target patients. However, the existence of the biological activities of ECa233 regarding anticancer activity has not been widely published in pre-clinical trials. Thus, the understanding of the bioactivity associated with the repression of cancer of ECa233 is interesting, and the research on this anticancer bioactive activity will provide valuable results that can further contribute to cancer drug development involving Centella Asiatica and ECa233 agents. In the present study, we investigated whether ECa233 alone or in combination with 5-FU could affect colorectal cancer cells. Moreover, we evaluated the toxicological aspects of ECa233 in the MRC-5 fibroblast cells.

\section{Materials and methods}

\section{ECa233 preparation}

ECa233 was kindly supplied by Siam Herbal Innovation Ltd. (Samut Prakan, Thailand). Total triterpenoids of standardized extract of ECa233 were quantified by LC-MS/MS analysis: madecassoside $(46.3 \%)$ and asiaticoside (41.6 \%). ECa233 was dissolved by $100 \%$ DMSO at $10 \mathrm{mg} / \mathrm{ml}$ and served as a stock solution. The stock solution at a concentration of $10 \mathrm{mg} / \mathrm{ml}$ was freshly diluted by culture medium to the final concentrations before treating the cells. The stock solution was kept in the refrigerator at $20^{\circ} \mathrm{C}$ to maintain its stability. The stock solute was freshly prepared in the hood that prevented the light from damaging the major constituent agents that appeared in the ECa233 isolation. 5-FU dry powder was suspended with sterile DMSO to the stock concentration at $10 \mathrm{mg} / \mathrm{ml}$ and served as the positive reagent as well as for testing in the drug combinative experiment.

\section{Chemicals and equipment}

$0.25 \%$ trypsin EDTA (Gibco, USA), $0.4 \%$ trypan blue (Sigma, USA), Dimethyl sulfoxide (DMSO) (Sigma, USA), RPMI-1640 medium (Gibco, USA), DMEM medium (Gibco, USA), Fetal bovine serum (Gibco, USA), Penicillin-streptomycin (Sigma, USA), 96-well plate (Corning, USA), 24-well plate (Corning, USA), Matrigel invasion chambers (Corning, USA), BD matrigel matrix (Biosciences, USA), T-25 cell culture flasks (Corning, USA), Fungizone ${ }^{\circledR}$ (Gibco, USA), and 3-(4,5dimethylthiazol-2-yl)-2,5-diphenyltetrazolium bromide (MTT reagent) (Sigma, USA). 


\section{Cell cultures}

SW-620 colorectal cancer cells were purchased from American Type Culture Collection (ATCC® Number: CCL-227 $7^{\mathrm{TM}}$ ). Cancer cells were maintained in RPMI-1640 media supplemented with $10 \%$ heatinactivated fetal bovine serum (FBS), $1 \%$ penicillin and streptomycin, and amphotericin $\mathrm{B}$ at $37{ }^{\circ} \mathrm{C}$ atmosphere with $5 \% \mathrm{CO}_{2}$ in the T-25 cell culture flasks. After cell growth at $95 \%$ confluence, the cells were trypsinized by trypsin-EDTA to harvest the growing cells. The $200 \mu \mathrm{l}$ of growing cells were pipetted for addition into the culture flasks to allow attachment overnight. Cells were subcultured every 3 days for maintenance of genetic stability. MRC-5 normal fibroblast cells were kindly provided from Dr. Sukannika tubtimsri, Division of Pharmaceutical Technology, Faculty of Pharmaceutical Sciences, Burapha University. Cells were cultured in DMEM media supplemented with $10 \% \mathrm{FBS}, 1 \%$ penicillin and streptomycin, and amphotericin B in an incubator.

\section{MTT cell viability assay}

The MTT assay was performed following manual guidance with slight modification [25] to determine the cytotoxicity of ECa233 on colorectal cancer cells and normal fibroblast cells. SW-620 cells at a density of 5,000 cells were cultured in a 96-well plate for 1 day. The media was removed from the 96-well plate and the fresh media was added to each well. Cells were treated with $10 \mu$ of ECa233 to reach the final concentrations of $5,10,25,50$, and $100 \mu \mathrm{g} / \mathrm{ml}$ for 24, 48, 72, and $96 \mathrm{~h}$. After the incubation period, $10 \mu \mathrm{l}$ of $5 \mathrm{mg} / \mathrm{ml}$ MTT in PBS solution was added to the 96-well plate, which was placed in an incubator for $3 \mathrm{~h}$. The yellow color of the MTT solution was changed to the insoluble purple formazan crystals by $\mathrm{NAD}(\mathrm{P}) \mathrm{H}$-dependent cellular oxidoreductase enzymes in viable cells. The absolute DMSO was added to each well to solubilize the formazan crystals. The 96-well plate was inserted into a microplate (Metertech, Taiwan) for reading the optical density (O.D.) value at $550 \mathrm{~nm}$. The percent cell viability was calculated using the equation;

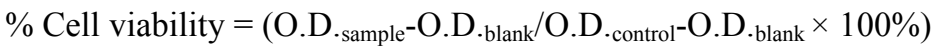

The cell culture wells that were used as the control did not receive the extract.

\section{Synergistic determination}

Drug combination studies quantified the synergy based on basic combinative knowledge [26]. SW620 cells were plated at a density of 5,000 cells in the 96 -well plate at $37^{\circ} \mathrm{C}$ in the incubator. The cells were treated with 30 and $40 \mu \mathrm{g} / \mathrm{ml}$ of ECa233 in the presence of $1,2.5,5,7.5,10,25$, and $50 \mu \mathrm{g} / \mathrm{ml} \mathrm{of} \mathrm{5-}$ FU and were compared to 5 -FU treatment alone for $48 \mathrm{~h}$. The $10 \mu \mathrm{l}$ of $5 \mathrm{mg} / \mathrm{ml}$ MTT solution was added to each well and placed in an incubator for $3 \mathrm{~h}$. After the incubation time at $37{ }^{\circ} \mathrm{C}$, the media was withdrawn and absolute DMSO was added to dissolve the formazan crystals. The plate was placed in a dark room. Viable cells were measured from the absorbance values at $550 \mathrm{~nm}$ using a microplate reader (Metertech, Taiwan).

\section{Drug safety testing}

MRC-5 fibroblast normal cells at a density of 5,000 cells/well were cultured with DMEM medium in the 96-well plate. The cells were incubated with ECa233 at 1, 2.5, 5, 10, 25, 50, and $100 \mu \mathrm{g} / \mathrm{ml}$ for 24, 48, 72, and $96 \mathrm{~h}$. Cell survival after being treated with ECa233 was determined using the MTT cell viability assay. O.D. values were read by a microplate reader (Metertech, Taiwan) at $550 \mathrm{~nm}$. The percentage of cell survival was determined and a graph of cell survival compared to untreated cells was generated.

\section{Colony formation assay}

The cells were cultured in complete RPMI-1640 media at a density of 5,000 cells/well in a 24-well plate for $24 \mathrm{~h}$ and then were cultured with 30,40 , and $50 \mu \mathrm{g} / \mathrm{ml}$ of ECa233 for $48 \mathrm{~h}$. The cultured media was aspirated and the fresh media was added to each well for 7 days. The medium was discarded from the experimental wells. Cells were washed with PBS solution to remove the residual medium. Cell colonies 
http://wjst.wu.ac.th

were fixed with acetic acid (3): methanol (7) for 15 minutes. Cells were stained with $0.5 \%$ crystal violet for 30 minutes. Cells were observed with a light microscope (10x) and randomly counted. Data were presented as \% colony formation.

\section{Cell migration assay}

The cells were seeded in a 24-well plate in RPMI-1640 containing $10 \%$ FBS until $100 \%$ confluence monolayers were reached. These cell monolayers were scratched with a $200 \mu 1$ micropipette tip to generate wounds in duplicates. The culture medium was withdrawn from the 24-well plate, washed with PBS solution to removed floating cells, and captured with an inverted microscope (objective 5x) at time 0 . The cells were cultured with 30,40 , and $50 \mu \mathrm{g} / \mathrm{ml}$ of ECa233 in RPMI-1640 containing $5 \%$ FBS and were then photographed at time 0,24 , and $48 \mathrm{~h}$. The number of cells that migrated was measured with ImageJ software (National Institute of Health, Bethesda, MD, USA). Data were presented as the percent of cells migrated.

\section{Matrigel invasion assay}

The cells were seeded at a density of 50,000 cells/well for $24 \mathrm{~h}$ in a $5 \% \mathrm{CO}_{2}$ atmosphere for $24 \mathrm{~h}$ and then treated with 30,40 , and $50 \mu \mathrm{g} / \mathrm{ml}$ of ECa233 for $48 \mathrm{~h}$. The polycarbonate membrane was coated with matrigel $(0.5 \mathrm{mg} / \mathrm{mL})$ and dried overnight in a laminar flow cabinet. Cells were trypsinized by trypsin-EDTA and seeded into the matrigel-coated invasion chamber (pore size: $8 \mu \mathrm{M}$; Corning, Cambridge, MA). The lower chamber of the system was filled with $500 \mu \mathrm{R}$ RMI-1640 medium containing $10 \%$ FBS as a chemo-attractant. After $48 \mathrm{~h}$ of incubation, the non-invading cells on the upper surface of the invasion chamber were wiped off with a cotton swab. Cells which migrated through the matrigel and crossed the invasion chamber were fixed with ice-cold methanol (AMRESCO, USA) and stained with crystal violet (Sigma, USA) for $30 \mathrm{~min}$. Cells were photographed with an inverted microscope (Olympus, Japan) and counted in 5 random fields. Data were expressed as \% proportional invasiveness comparing treated cells with untreated cells.

\section{Human MMP-9 immunosorbent assay (ELISA)}

Cancer cells were cultured at a density of 50,000 cells/well in a 24-well plate with 30, 40, and 50 $\mu \mathrm{g} / \mathrm{ml}$ of ECa233 for $48 \mathrm{~h}$. The supernatant was collected from the culture plates. Tissue culture samples were diluted with standard diluent buffer $(1: 20)$. The sample volume was added in each well and covered with aluminum foil. The plate was incubated at room temperature for $2 \mathrm{~h}$. After incubation, $100 \mu \mathrm{l}$ of biotinylated $\mathrm{Hu}$ MMP-9 Biotin conjugate solution, streptavidin-HRP working solution, and stabilized chromogen were added to the plate. Finally, $100 \mu \mathrm{l}$ of stop solution was added to stop the reaction occurring in each well, with monitoring by the blue color changing to yellow. The MMP-9 protein contents were determined using the ELISA assay. The absorbance of each well was estimated by a microplate reader at $450 \mathrm{~nm}$. MMP-9 concentrations were determined by comparison with graph standard curves. The MMP-9 protein levels were shown as $\mathrm{pg} / \mathrm{ml}$.

\section{Statistical analysis}

Data were presented as mean \pm SEM. Graphs were generated using Graphpad Prism software Ver. 7.0 (Graphpad $^{\mathrm{TM}}$ 7.0, San Diego, California). One-way ANOVA with Tukey's Honestly Significant Difference (HSD) post hoc test was used to analyze the data from the 3 independent experiments.

\section{Results and discussion}

Anti-cancer activity of ECa233 on SW-620 colorectal cancer cells

The sensitivity of colorectal cancer cell lines to ECa233 was estimated by the MTT cell viability assay. As illustrate data in Figure 2, cells were treated with ECa233 at 5, 10, 25, 50, and $100 \mu \mathrm{g} / \mathrm{ml}$ for $24,48,72$, and $96 \mathrm{~h}$. The sensitivity of the positive control cells to chemotherapeutic drugs (5-FU) in various concentrations $(1,10$, and $100 \mu \mathrm{g} / \mathrm{ml})$ were estimated. The viability of cells after being treated with ECa233 at the concentrations of 5 and $10 \mu \mathrm{g} / \mathrm{ml}$ was inhibited approximately $20 \%$ after being 
treated with ECa233 (Figure 2a), while treatment with ECa233 at 50 and $100 \mu \mathrm{g} / \mathrm{ml}$ significantly decreased the \% cell viability of the SW-620 cells approximately $75-90 \%$ after treatment for $24 \mathrm{~h}(p<$ 0.001). The results demonstrated that high doses of ECa233 (50 and $100 \mu \mathrm{g} / \mathrm{ml})$ potentially inhibit the SW-620 cells proliferation in a time- and dose-dependent manners after treatment for 48, 72, and $96 \mathrm{~h}$ (Figures 2b - 2d), which showed that the cells were very sensitive after exposure to ECa233; however, no side effects to normal cells were observed. These data indicate that the effectiveness of the natural active ingredients of Centella Asiatica can support the development of a high-quality herbal medicine for cancer.

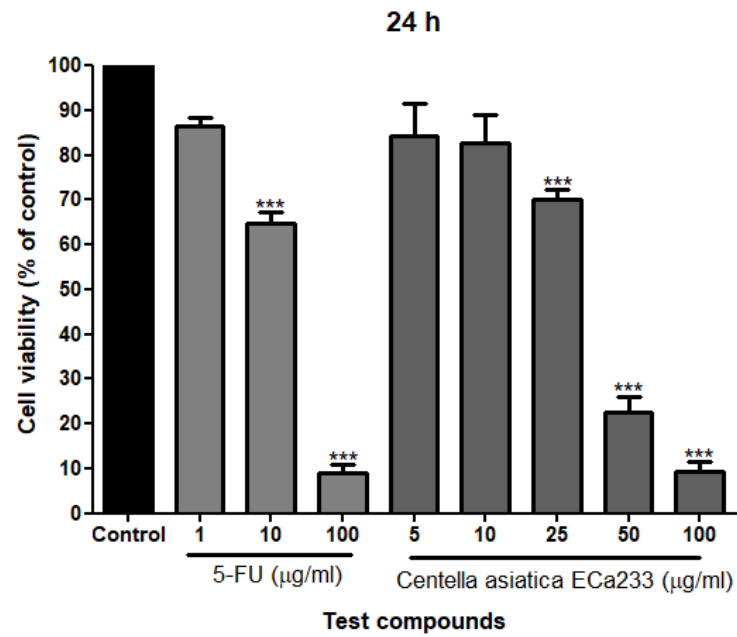

(a)

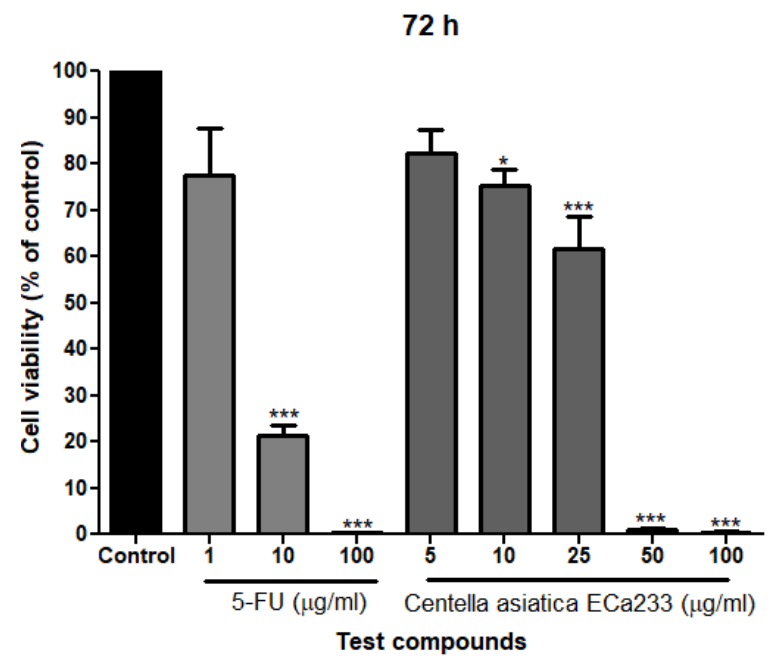

(c)

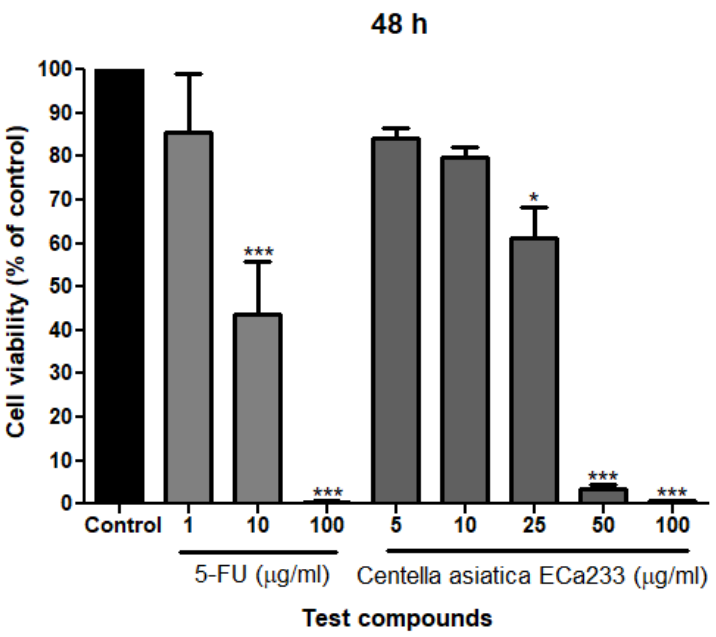

(b)

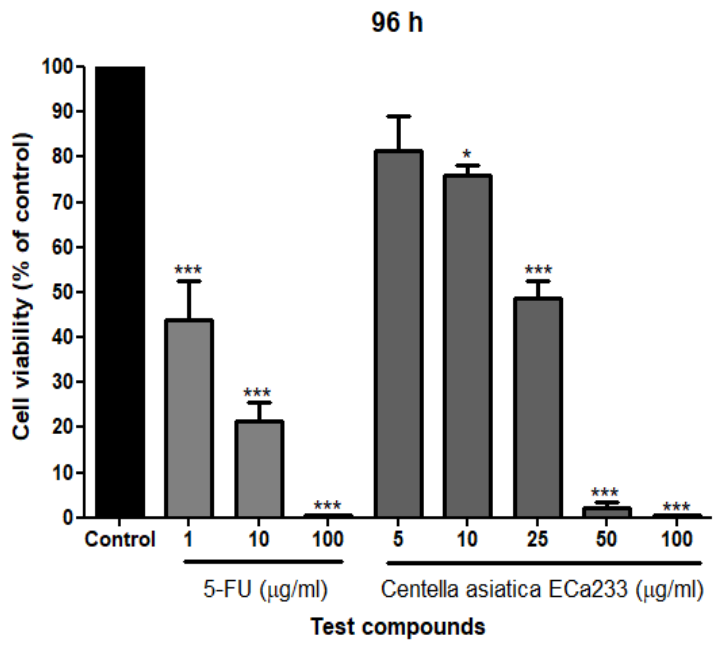

(d)

Figure 2 Effects of ECa233 on SW-620 colorectal cancer cells. Cells were exposed to $5-100 \mu \mathrm{g} / \mathrm{ml}$ of ECa233 for 24 (a), 48 (b), 72 (c), and 96 (d) h. The percentage of cell viability was determined by MTT cell viability assay. The $5-\mathrm{FU}$ at $1-100 \mu \mathrm{g} / \mathrm{ml}$ was used as a positive control in the experiments. The results were represented as a percentage of control. Data were expressed as the mean $\pm \operatorname{SEM}(\mathrm{n}=3)$. *** $p$ $<0.001$, significantly different from the control, ${ }^{*} p<0.01$, significantly different from the control, $* p<$ 0.05 , significantly different from the control. 
http://wjst.wu.ac.th

Determination of the inhibitory concentration (IC) at 20, 40, and $80 \%$ of ECa233 in SW-620 colorectal cancer cells

Calculations of the inhibitory concentrations at 20,40, and $80 \%$ of ECa233 to cellular growth in a 96-well plate were performed. The graph shows the percent cytotoxicity of ECa233-treated colorectal cancer cells exposed to a wide range of concentrations of ECa233, which greatly decreased cell viability in a concentration-dependent manner. The $\mathrm{IC}_{20}$ was found to be $6.810 \pm 5.771 \mu \mathrm{g} / \mathrm{ml}$ after $24 \mathrm{~h}$ of incubation. Consistently, after an incubation time of $48 \mathrm{~h}$, the viable cells were decreased regarding the number of cancer cells growing in the 96-well plate. The $\mathrm{IC}_{20}$ value determined as shown in the graph cytotoxicity to SW-620 cells (\%) was $3.251 \pm 2.098 \mu \mathrm{g} / \mathrm{ml}$. Moreover, at 72 and $96 \mathrm{~h}$ after treating the cancer cells, the number of viable cells were highly sensitized to the effects of ECa233. The $\mathrm{IC}_{20}$ in this timing was $1.987 \pm 1.987$ and $1.178 \pm 1.178 \mu \mathrm{g} / \mathrm{ml}$ after incubation.

To determinate the $\mathrm{IC}_{20}, \mathrm{IC}_{40}$, and $\mathrm{IC}_{80}$ values of ECa233 in SW-620 cells after treatment for 24,48 , 72 , and $96 \mathrm{~h}$

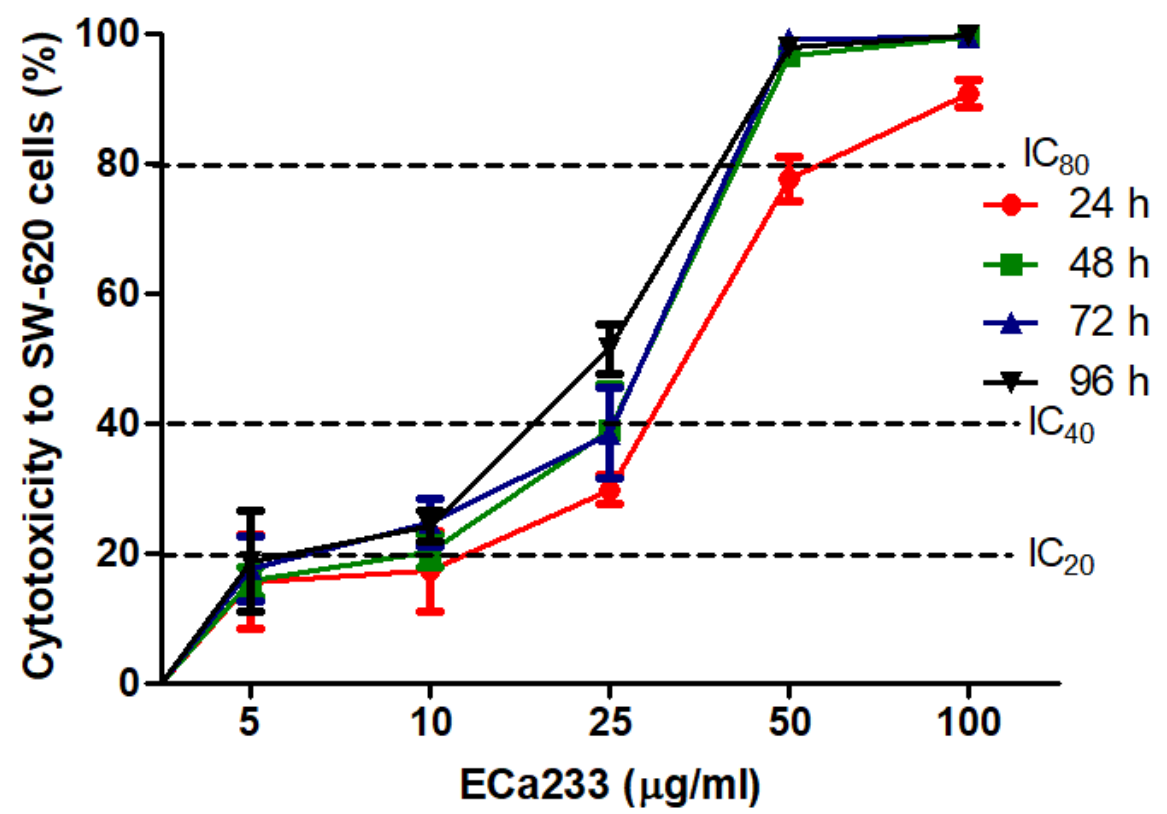

Table 1 Inhibitory concentrations of ECa233 at 20, 40, and $80 \%$ of ECa233 on SW-620 cells after treatment for $24,48,72$, and $96 \mathrm{~h}$.

\begin{tabular}{llll}
\hline Cell lines (SW-620) & \multicolumn{4}{l}{ Inhibitory Concentration of ECa233 at 20, $\mathbf{4 0}$ and $\mathbf{8 0} \%$} \\
\hline Time $(\mathrm{h})$ & $\mathrm{IC}_{20}(\mu \mathrm{g} / \mathrm{ml})$ & $\mathrm{IC}_{40}(\mu \mathrm{g} / \mathrm{ml})$ & $\mathrm{IC}_{80}(\mu \mathrm{g} / \mathrm{ml})$ \\
\hline $\mathbf{2 4}$ & $6.810 \pm 5.771$ & $29.99 \pm 3.929$ & $77.63 \pm 1.245$ \\
\hline $\mathbf{4 8}$ & $3.251 \pm 2.098$ & $22.95 \pm 2.651$ & $65.19 \pm 1.433$ \\
\hline $\mathbf{7 2}$ & $1.987 \pm 1.987$ & $20.62 \pm 2.764$ & $63.99 \pm 1.226$ \\
\hline $\mathbf{9 6}$ & $1.178 \pm 1.178$ & $17.09 \pm 3.381$ & $62.15 \pm 1.117$ \\
\hline
\end{tabular}

Synergistic anti-cancer activity of ECa233 and 5-fluorouracil on inhibition of cell viability in SW-620 colorectal cancer cells. 
http://wjst.wu.ac.th

To examine the drug combinative activity of ECa233 at $20 \mu \mathrm{g} / \mathrm{ml}$ plus 5-FU. As illustrate data in Figure 3, the results obtained from the MTT assay demonstrated that ECa233 at $10 \mu \mathrm{g} / \mathrm{ml}$ can reduce the percentage of cell viability approximately $20 \%$ and that the number of cancer cells that ECa233 at 20 $\mu \mathrm{g} / \mathrm{ml}$ (Figure 3a) killed was not significantly different from that using the 5-FU treatment alone. Therefore, the selective dosing rates chosen for the drug combinative experiments were 30 and $40 \mu \mathrm{g} / \mathrm{ml}$ of ECa233. In the experiments, cells were treated with 30 and $40 \mu \mathrm{g} / \mathrm{ml}$ of ECa233 in the presence of various concentrations of 5-FU $(0,1,2.5,5,7.5,10,25$, and $50 \mu \mathrm{g} / \mathrm{ml})$ for $48 \mathrm{~h}$. After co-treatment using 5-FU with $30 \mu \mathrm{g} / \mathrm{ml} \mathrm{ECa233} \mathrm{(Figure} \mathrm{3b),} \mathrm{the} \mathrm{viability} \mathrm{of} \mathrm{the} \mathrm{SW-620} \mathrm{cancer} \mathrm{cells} \mathrm{was} \mathrm{dramatically}$ decreased by approximately $60-70 \%$. Additionally, $40 \mu \mathrm{g} / \mathrm{ml}$ of ECa233 plus 5-FU (Figure 3c) also significantly reduced the cell viability of the SW-620 cells. The percentage of cell viability rapidly decreased when the concentration of 5-FU was increased in the presence of ECa233 at $30 \mu \mathrm{g} / \mathrm{ml}$. However, the cell viability was superiorly decreased after the concentration of ECa233 was increased to $40 \mu \mathrm{g} / \mathrm{ml}$, and the inhibitory effects revealed approximately the same results after treatment with the various doses of 5 -FU.

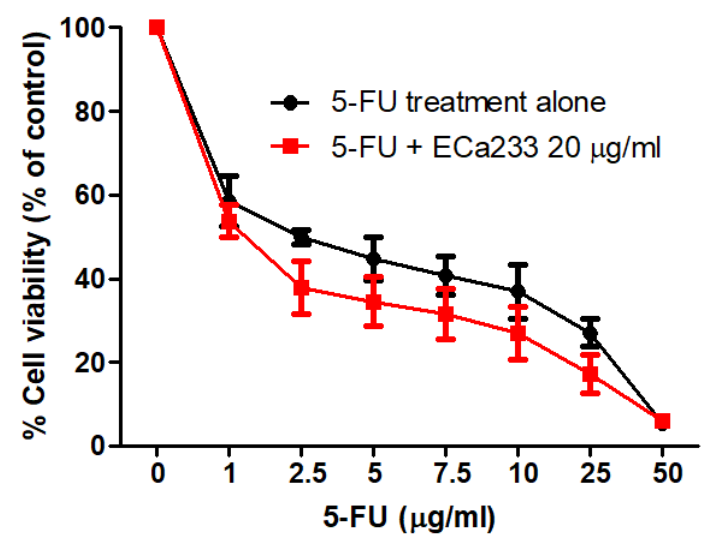

(a)

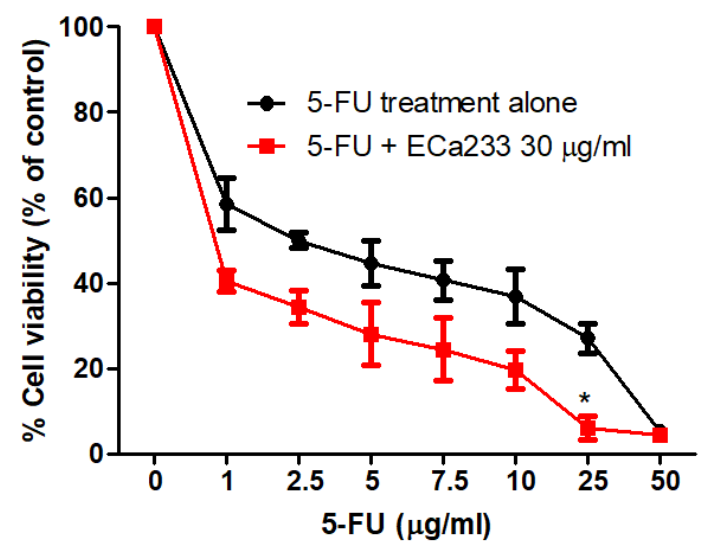

(b)

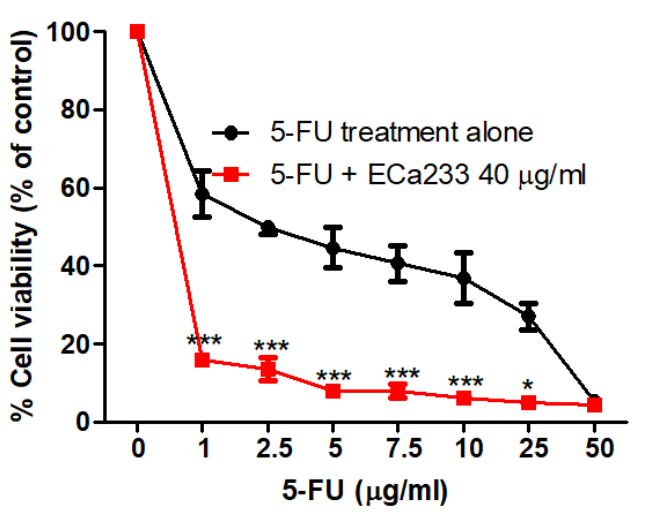

(c)

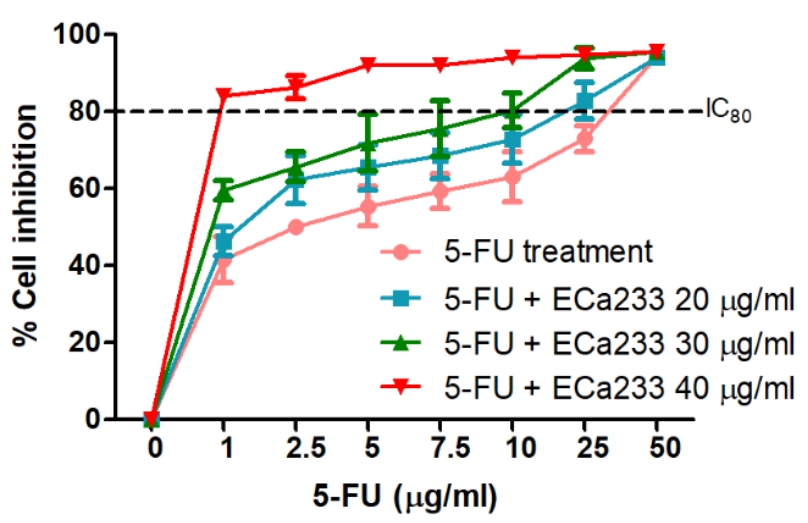

(d)

Figure 3 Effects of 5-FU and ECa233 on cell viability of SW-620 colorectal cancer cells. Cells were coincubated with ECa233 (20 (a), 30 (b), and 40 (c) $\mu \mathrm{g} / \mathrm{ml})$ and 5-FU (1, 2.5, 5, 7.5, 10, 25, and 50 $\mu \mathrm{g} / \mathrm{ml})$ for $48 \mathrm{~h}$. The percentage of cell viability was determined by MTT cell viability assay. The results were presented as a percentage of cell viability and percentage of cell inhibition (d). Data were presented as the mean $\pm \operatorname{SEM}(\mathrm{n}=3) .{ }^{* * *} p<0.001$ compared with 5 -FU treatment alone, ${ }^{*} p<0.05$ compared with 5 -FU treatment alone. 
http://wjst.wu.ac.th

Table $2 \mathrm{IC}_{80}$ values $(\mu \mathrm{g} / \mathrm{ml})$ of 5 -FU in combination with ECa233 in various concentrations.

\begin{tabular}{lll}
\hline Test compound & IC $_{\mathbf{8 0}}(\boldsymbol{\mu g} / \mathbf{m l})$ & $\boldsymbol{p}$-value \\
\hline $\mathbf{5 - F U}$ treatment alone & $32.52 \pm 2.218$ & - \\
\hline $\mathbf{5 - F U}+\mathbf{E C a 2 3 3 ~} 20 \boldsymbol{\mu g} / \mathbf{m l}$ & $26.36 \pm 3.309$ & $\mathrm{~ns}$ \\
\hline $\mathbf{5 - F U}+\mathbf{E C a 2 3 3 ~} 30 \boldsymbol{\mu g} / \mathbf{m l}$ & $16.84 \pm 5.900$ & $\mathrm{~ns}$ \\
\hline $\mathbf{5 - F U}+\mathbf{E C a 2 3 3 ~} 40 \boldsymbol{\mu g} / \mathbf{m l}$ & $<1 \mu \mathrm{g} / \mathrm{ml}$ & $* * *$
\end{tabular}

$*$ ns = not significant

Effects of ECa233 on cell viability of normal MRC-5 fibroblast cells

As illustrate data in Figure 4, to investigate the possible cytotoxicity, MRC-5 normal fibroblast cells were treated with the various concentrations of ECa233 at 1, 2.5, 5, 10, 25, 50, and $100 \mu \mathrm{g} / \mathrm{ml}$ in a 96-well plate for 24 (Figure 4a), 48 (Figure 4b), 72 (Figure 4c), and 96 (Figure 4d) h. The results demonstrated that ECa233 has minimal effects on normal cells. The normal cells maintained sustainable growth under normal conditions indicating that the multiple constituents that appear in the ECa233 powder are not more toxic than the cancer cells. These data indicate that the purified powder is non-toxic to normal cells. The results suggest that ECa233 in combination with 5-FU could become a potential therapeutic agent against colorectal cancer cells without apparent toxicity to normal cells.

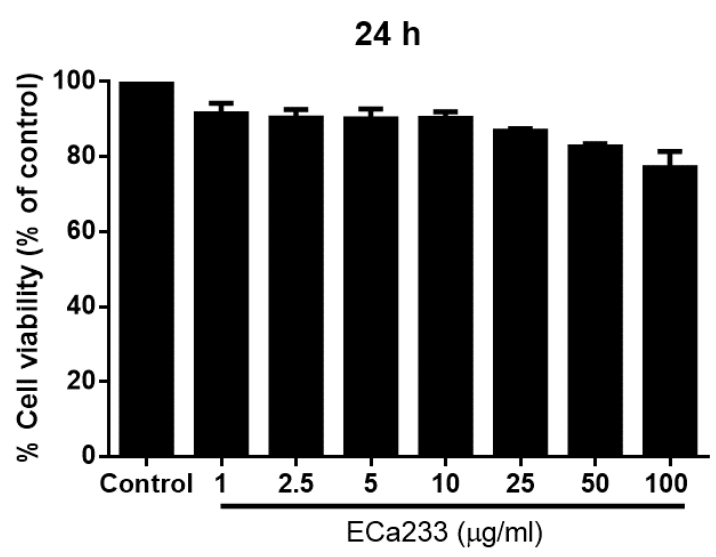

(a)

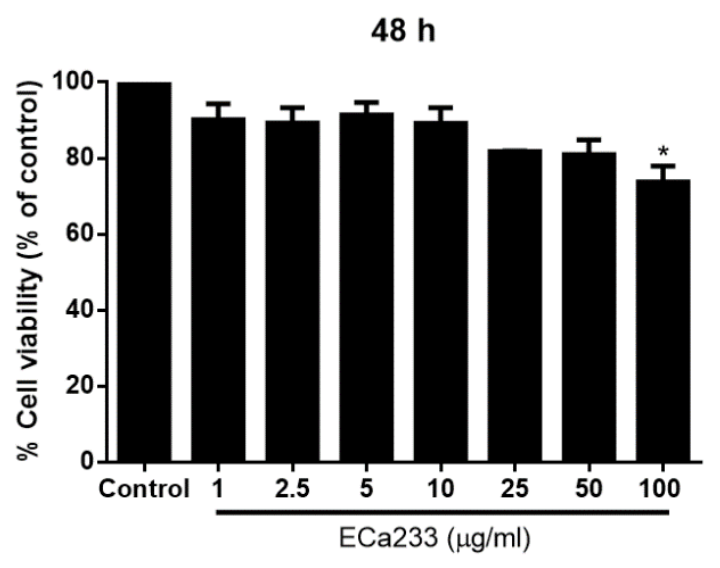

(b) 
$72 \mathrm{~h}$

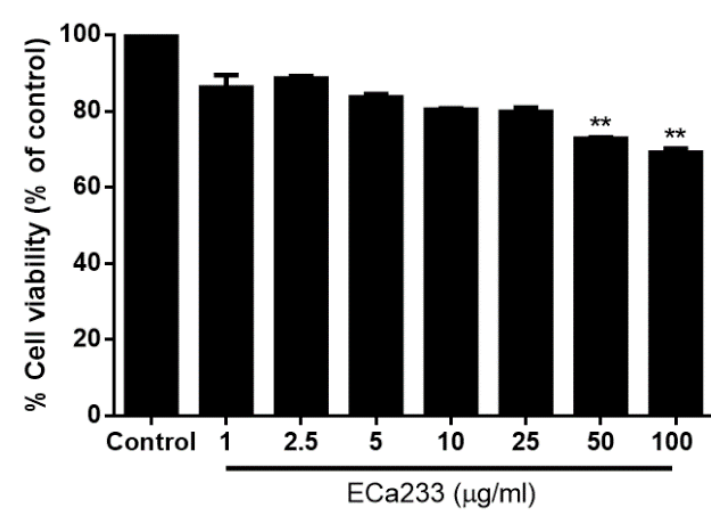

(c)
$96 \mathrm{~h}$

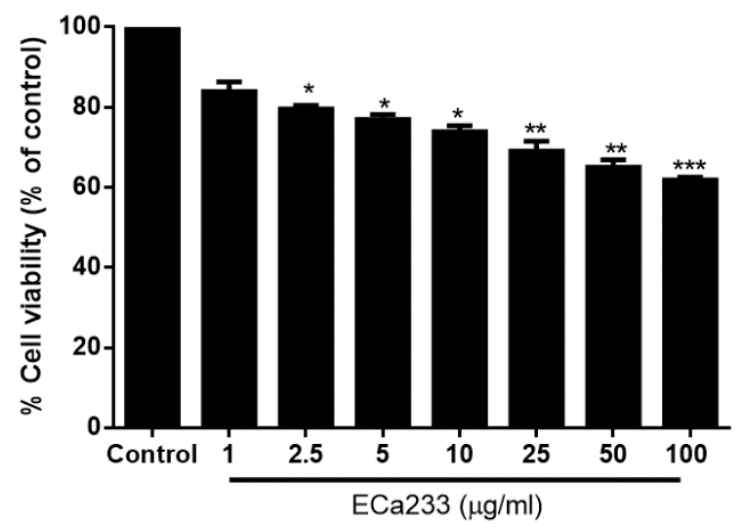

(d)

\begin{tabular}{cccccccc}
\hline \multirow{2}{*}{$\begin{array}{c}\text { Time } \\
\text { (h) }\end{array}$} & \multicolumn{7}{c}{ Percentage of cell viability after treatment with ECa233 (\% Cell viability) } \\
\cline { 2 - 8 } & $\mathbf{1}$ & $\mathbf{2 . 5}$ & $\mathbf{5}$ & $\mathbf{1 0}$ & $\mathbf{2 5}$ & $\mathbf{5 0}$ & $\mathbf{1 0 0}$ \\
\hline $\mathbf{2 4}$ & $91.46 \pm 2.785$ & $90.27 \pm 2.284$ & $90.05 \pm 2.686$ & $90.19 \pm 1.804$ & $86.78 \pm 0.7217$ & $82.61 \pm 0.8147$ & $77.07 \pm 4.346$ \\
\hline $\mathbf{4 8}$ & $90.13 \pm 4.197$ & $89.27 \pm 3.977$ & $91.39 \pm 3.280$ & $89.19 \pm 4.132$ & $81.78 \pm 0.1472$ & $80.95 \pm 3.892$ & $73.73 \pm 4.223$ \\
\hline $\mathbf{7 2}$ & $86.17 \pm 3.283$ & $88.55 \pm 0.6252$ & $83.61 \pm 0.8668$ & $80.39 \pm 0.3142$ & $79.81 \pm 1.123$ & $72.72 \pm 0.3443$ & $69.09 \pm 1.079$ \\
\hline $\mathbf{9 6}$ & $83.94 \pm 2.393$ & $79.57 \pm 0.8968$ & $76.94 \pm 1.209$ & $73.88 \pm 1.544$ & $69.04 \pm 2.486$ & $65.04 \pm 1.833$ & $61.84 \pm 0.6860$ \\
\hline
\end{tabular}

Figure 4 Effects of ECa233 on cell viability of MRC-5 fibroblast cells. Normal cells were tested with various concentrations of ECa233 (1, 2.5, 5, 10, 25, 50, and $100 \mu \mathrm{g} / \mathrm{ml})$ for 24 (a), 48 (b), 72 (c), and 96 (d) h. The cell survival of the non-toxic cells was measured by MTT cell viability assay. The results were presented as a percentage of cell viability. Data were presented as the mean $\pm \operatorname{SEM}(n=3)$.

\section{Effects of ECa233 on cell colony formation in SW-620 colorectal cancer cells}

Cell growth is an essential step for the proliferation of cancer cells, which can spontaneously expand from a small colony to form a large colony. Therefore, it is essential to investigate the potential extension of the effects of ECa233 on the ability to form and expanding of the numbers of cells in colonization. Colony formation assay was used to evaluate the cancer cells' proliferation in relation to the forming of large colonies. As illustrate data in Figure 5, to assess the effects on colony growth in the cultured plate, after treating cancer cells with ECa233, cell growth and proliferation in normal culture media were allowed to clarify its potential in suppressing the colony formation (Figure 5a). The percentage of colony formation in the treated group was extremely inhibited by ECa233 (Figure $\mathbf{5 b}$ ). 
Control

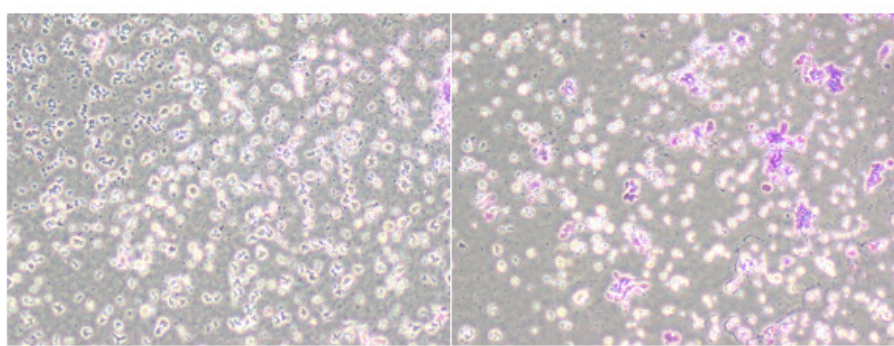

$\mathrm{ECa} 23340 \mu \mathrm{g} / \mathrm{ml}$

$\mathrm{ECa} 23350 \mu \mathrm{g} / \mathrm{ml}$

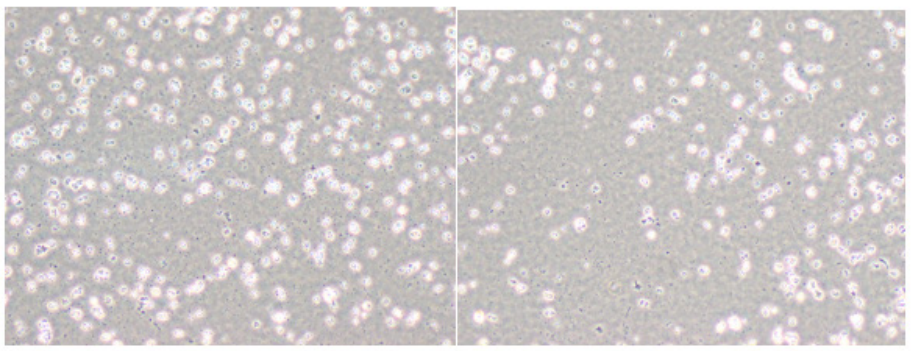

(a)

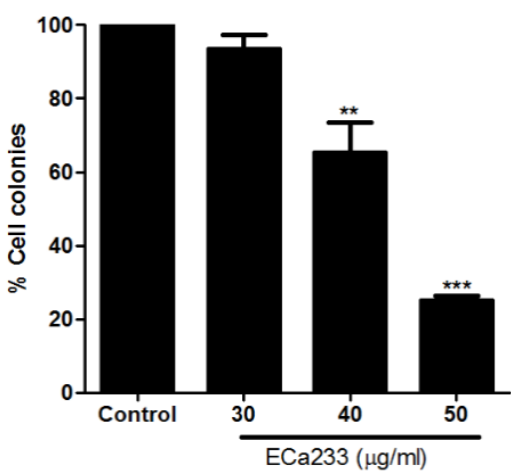

(b)

\begin{tabular}{lllll}
\hline Number of colony & \multicolumn{4}{l}{ Test compounds (ECa233) } \\
\hline Time & Control & $30 \mu \mathrm{g} / \mathrm{ml}$ & $40 \mu \mathrm{g} / \mathrm{ml}$ & $50 \mu \mathrm{g} / \mathrm{ml}$ \\
\hline $48 \mathrm{~h}$ & $100.0 \pm 0.0$ & $93.374 \pm 2.717$ & $65.149 \pm 5.891$ & $25.005 \pm 0.997$ \\
\hline
\end{tabular}

Figure 5 Cells were treated with 30,40 , and $50 \mu \mathrm{g} / \mathrm{ml}$ of ECa233 for $48 \mathrm{~h}$. The culture cells were aspirated from the old media and cultured with RPMI-1640 medium for 7 days. Cells from the culture plate were kept and were fixed with fixing reagents (acetic acid: methanol) and the attached cells were replaced in the cultured plate at room temperature. The attached cells were stained with crystal violet and photographed by light microscope (a and b). Cells were manually counted to investigate the results. Data were expressed as a percentage of colonies. $* * * p<0.001$, significantly different from the control, $* * p<$ 0.01 , significantly different from the control.

\section{Effects of ECa233 on cell migration in SW-620 colorectal cancer cells}

Cell migration is an essential step in cancer metastasis. ECa233 was evaluated for its effects on the migratory potential of SW-620 cells by using the scratch assay, which was performed to test whether various concentrations of ECa233 affect the ability of colorectal cancer cells to migrate at wound closings. Cells were treated with ECa233 at 30,40, and $50 \mu \mathrm{g} / \mathrm{ml}$ to analyze the potential of natural substances, which were in a range of concentrations near an $\mathrm{IC}_{50}$ value, and the expected outcome was that it might not affect cell death. As illustrate data in Figure 6, cells were treated with ECa233 at 30, 40, and $50 \mu \mathrm{g} / \mathrm{ml}$ to analyze the potential of ECa233. The percentage of cells that migrated was decreased after being treated with 30 and $40 \mu \mathrm{g} / \mathrm{ml}$ for $24 \mathrm{~h}$ and $48 \mathrm{~h}(p<0.01)$. In particular, the higher concentration of ECa233 at $50 \mu \mathrm{g} / \mathrm{ml}$ extremely regressed the potential of cancer cells to migrate from the edge of the wound scratches $(p<0.001)$ (Figures 6a and $\mathbf{6 b}$ ). 


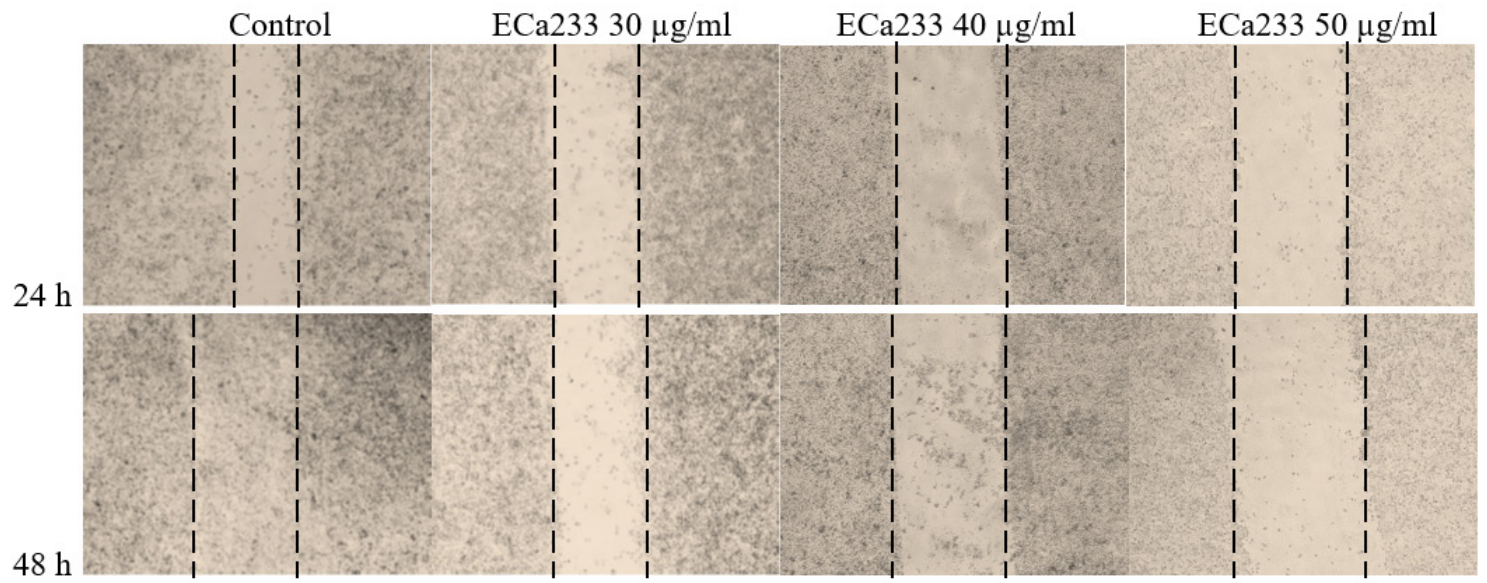

(a)

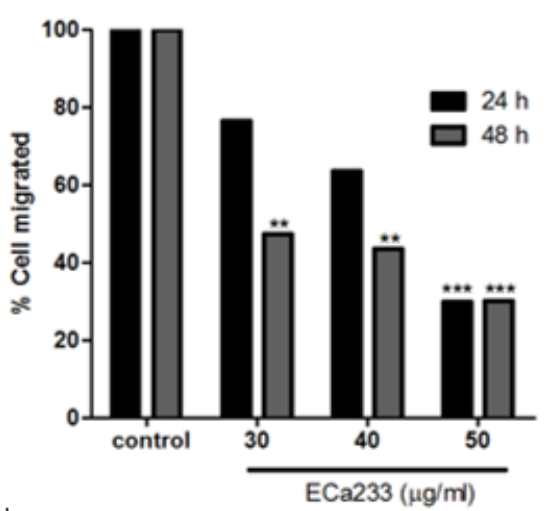

\begin{tabular}{lllll}
$\begin{array}{l}\text { Percent of cell } \\
\text { migration }\end{array}$ & Test compounds (ECa233) & \\
\hline Time (h) & Control & 30 & 40 & 50 \\
& & $\mu \mathrm{g} / \mathrm{ml}$ & $\mu \mathrm{g} / \mathrm{ml}$ & $\mu \mathrm{g} / \mathrm{ml}$ \\
\hline 24 & $100.0 \pm$ & $76.30 \pm$ & $63.45 \pm$ & $29.87 \pm$ \\
& 0.0 & 11.860 & 9.607 & 8.014 \\
\hline 48 & $100.0 \pm$ & $47.38 \pm$ & $43.64 \pm$ & $30.16 \pm$ \\
& 0.0 & 9.664 & 17.130 & 6.000 \\
\hline
\end{tabular}

(b)

Figure 6 The confluent monolayers were used to generate wounds by scratching with a pipette tip. Cells were incubated in RPMI-1640 with $5 \%$ FBS underlying with or without ECa233 (30, 40, and 50 $\mu \mathrm{g} / \mathrm{ml})$ for 24 and $48 \mathrm{~h}$ (a and b). Cells were photographed with phase-contrast microscopy. The data in the migration assay were represented as mean \pm SEM from 3 independent experiments. *** $p<0.001$, significantly different from the control, ${ }^{* *} p<0.01$, significantly different from the control.

Effects of ECa233 on cell invasion and MMP-9 protein expression in SW-620 colorectal cancer cells

As illustrate data in Figure 7, to confirm the results obtained from the scratch assay, the matrigel invasion assay was performed to examine the effectiveness of ECa233 on the metastatic process. Matrigel invasion assays were performed using Boyden Chambers coated with matrigel. Cells were incubated with ECa233 at 30, 40, and $50 \mu \mathrm{g} / \mathrm{ml}$ for $48 \mathrm{~h}$. The percentage of cell invasion in the treated group was decreased compared to the control group (Figures $\mathbf{7 a}$ and $\mathbf{7 b}$ ). These results collectively support that ECa233 has a truly inhibitory effect on cancer cell invasion through the matrigel invasion chambers. Based on the assessment of the effects of ECa233 on MMP-9 protein expression by ELISA, the results demonstrated that ECa233 gradually decreased MMP-9 protein content in serum ECa233 treated cells (Figure 7c). 
Control

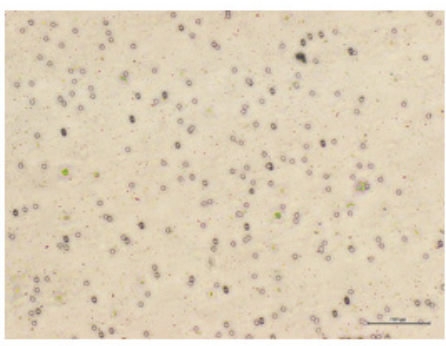

$\mathrm{ECa} 23340 \mu \mathrm{g} / \mathrm{ml}$

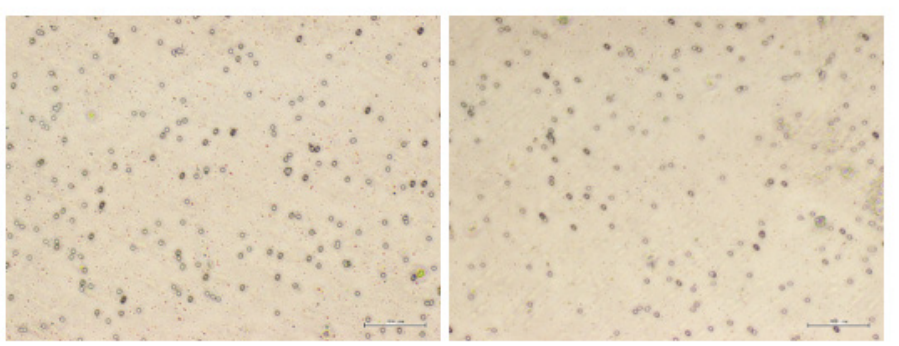

(a)

$\mathrm{ECa} 23330 \mu \mathrm{g} / \mathrm{ml}$

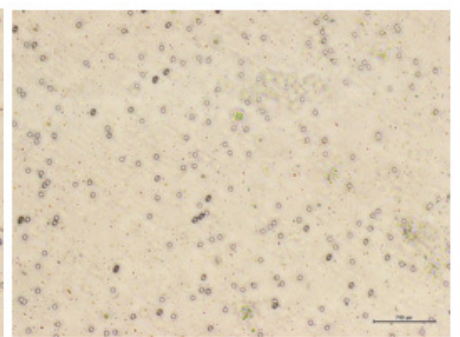

$\mathrm{ECa} 23350 \mu \mathrm{g} / \mathrm{ml}$

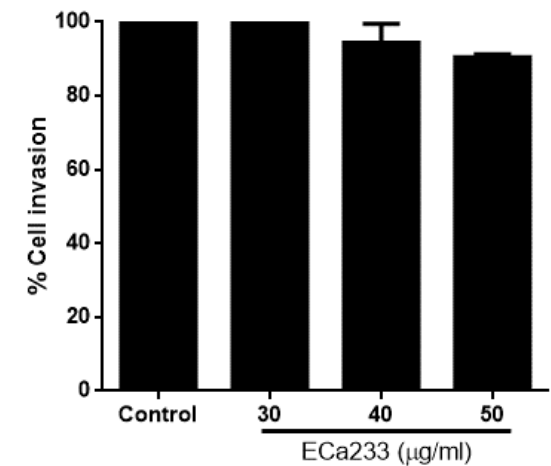

(b)

\begin{tabular}{lllll}
\hline Percent of cell invasion & \multicolumn{4}{l}{ Test compounds (ECa233) } \\
\hline Time & Control & $30 \mu \mathrm{g} / \mathrm{ml}$ & $40 \mu \mathrm{g} / \mathrm{ml}$ & $50 \mu \mathrm{g} / \mathrm{ml}$ \\
\hline $48 \mathrm{~h}$ & $100.0 \pm 0.0$ & $99.64 \pm 0.3595$ & $94.37 \pm 2.971$ & $90.52 \pm 0.4686$ \\
\hline
\end{tabular}

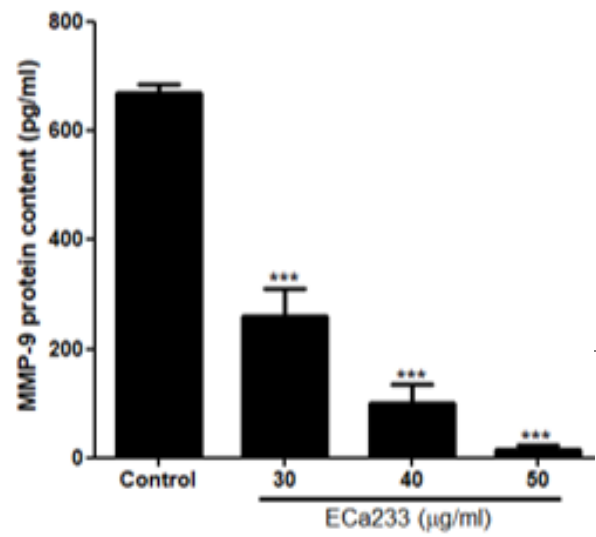

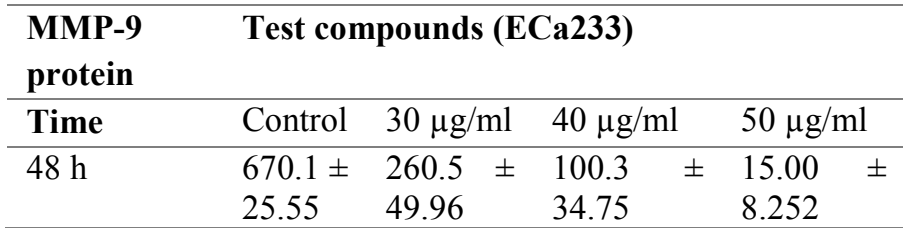

(c)

Figure 7 Effects of ECa233 on cell invasion by matrigel invasion assay. Cells were suspended with serum-free RPMI-1640 medium before being overlaid in the upper chamber of the transwell. After incubation with ECa233 (30, 40, and $50 \mu \mathrm{g} / \mathrm{ml})$ for $48 \mathrm{~h}$, invaded cells were stained with crystal violet and photographed by microscope (a and $\mathbf{b}$ ). The data were shown as a percentage of cell invasion. The results were represented as mean \pm SEM from 3 independent experiments. Regarding the effects of ECa233 on the protein expression (MMP-9) of colorectal cancer cells, the cell supernatant was determined by the ELISA kit (c). The data showed MMP-9 protein content $(\mathrm{pg} / \mathrm{ml})$ as mean \pm SEM from 3 independent experiments. ${ }^{* * *} p<0.001$, significantly different from the control. 
http://wjst.wu.ac.th

\section{Discussion}

Chemotherapy is a conventional way to reduce the rate of cancer progression. However, the recurrence of adverse side effects is a significant problem after the long-term use of the drugs. Therefore, it is essential to find a promising inhibitory cancer agent to sensitize the resistance power in malignant cancer cells. ECa233 can be an effective pathway to control malignant growths in the body by inducing cell death via suppressing the cellular growth through a synergistic effect with conventional 5-FU chemotherapy. However, monitoring the other adverse effects occurring during the therapeutic period is also the main concern. In the present study, the primary results of ECa233 on the survival of colorectal cancer cells was demonstrated. ECa233 strongly exhibits anti-cancer activities in a dose-dependent fashion and time-dependent manner. The SW-620 colorectal cancer cells were extremely sensitive to ECa233 extraction and non-toxic doses of ECa233 were less toxic to normal cells. Moreover, cotreatment of 5-FU and ECa233 was shown to potentially affect the stability of cancer cells by decreasing the viability of tumor cells. 5-FU acts as a drug affecting cell-cycle specificity during the G1-S phase of the cell cycle by inhibiting thymidylate synthase (TS) and also inducing DNA and RNA strand breaks, which leads to cancer apoptosis through incorporate DNA and RNA strands [27]. P21 protein plays a specifically important role in the checkpoint of the G1 phase, with 5-FU working as an inducer of the expression of the $\mathrm{P} 21$ protein, which has been shown to have a role in the tumor suppressor activity that mediates its biological effect by binding to $\mathrm{CDK}$ and the widely distributed effects resulting from inhibiting the phosphorylation of the retinoblastoma protein $(\mathrm{Rb})$ by the cyclin-CDK complex caused by cyclin A-CDK2, cyclin E-CDK2, cyclin D1-CDK4, and cyclin D2-CDK4 complexes [28]. Furthermore, Centella Asiatica has been reported as the underlying mechanism influencing the apoptosis in cancer cells through increasing the cell cycle arrest and accumulation of cells in the G1-S phase of the cell cycle. Centella Asiatica induces G1-S and G2-M arrest in Caco-2 cells accompanied by apoptosis activation and accumulation of cyclin B1 protein in the cells. These findings indicate that Centella Asiatica extract inhibits cell proliferation via modulating the cell cycle events by partial cell cycle arrest, at least partially by the accumulation of cyclin B1 protein [29]. Consistent with previous reports, it was demonstrated that Asiatic acid, the major component of Centella Asiatica, can mediate the cytotoxic effect by inhibition of the proliferation and migration as well as the induced apoptosis of colon cancer cells by regulating Pdcd4 via the $\mathrm{PI} 3 \mathrm{~K} / \mathrm{Akt} / \mathrm{mTOR} / \mathrm{p} 70 \mathrm{~S} 6 \mathrm{~K}$ signaling pathway and downregulated epithelial-mesenchymal transition (EMT). Moreover, the G2-M and S phase progression was delayed and apoptotic bodies in colon cancer cells treated with Asiatic acid were widely observed [30].

5-FU is commonly used as a chemotherapeutic drug in first-line products to reduce the size and prevent abnormal growth in primary organs. 5-FU is routinely used in the management of colorectal cancer patients. However, the serious problem that often occurs in patients who receive this drug is resistance to 5-FU [31]. Therefore, improving the response in patients is necessarily required. The novel natural chemical that can sensitize a tumor cell to chemotherapy will have great potential in the treatment of cancer. Several studies have revealed that curcuminoid can sensitize colorectal cancer cells to 5-FU and is exclusive in attention, and thus, it is beneficial to current approaches to the management of patients with metastatic colorectal cancers [32]. Our findings in this study represent the effects of ECa233 with traditional chemotherapy (5-FU) by mediating its anti-proliferative and anti-growth effects in the synergistic testing. These results suggest that the biological activities of ECa233, when used as a combinative therapy at a non-toxic dose, were more effective than ECa233 alone or 5-FU residual exactly. These data indicate that the combined effect of ECa233 and 5-FU on the viable cells of colorectal cancer is superior to 5-FU alone in vitro. The concentration of ECa233 was used at lower levels, which are safe to normal cells. Our findings in the present study indicate that the further development of ECa233 containing madecassoside and asiatocoside as alternative medicine is worthwhile, which will require developing a suitable formulation with highly effective properties that have impacts on cancer cells. Our findings in this study provide the basic preclinical data that may be amplified in further investigation to confirm its use as part of a novel and promising combinative therapy as well as an underlying mechanism. MRC-5 fibroblast cells (MRC-5 cells) were not more sensitive than the SW-620 cells to ECa233 treatment. At $24 \mathrm{~h}$, when the concentration exceeds $100 \mu \mathrm{g} / \mathrm{ml}$, the MRC-5 cells in total will have the percentage of cell viability at $78 \%$, suggesting that ECa233 has no effect on normal cellular growth, 
indicating valuable safety to humans. However, after incubation periods of 72 and $96 \mathrm{~h}$, normal cells were sensitive to ECa233 and the percentage of cell viability was approximately $62-84 \%$. In light of these results, the ECa233 extract was shown to be superior as a synergistic attacking drug with 5-FU in cancer cells compared to when ECa233 was tested as a pure compound and its compatibility is selective to cancerous cells rather than normal cells. It is possible that the multiple constituents contained in this extract have synergistic therapeutic actions due to pharmacodynamic synergism interactions. Interestingly, the $\mathrm{IC}_{50}$ value in normal fibroblast cells could not be estimated at the concentrations of ECa233 used. It is suggested that the safe treatment using ECa233 combined with 5-FU be developed as a combination therapy in the future. Monitoring the number of cells adhering in the testing with the 24-well plate demonstrated that the number of positive colonies was strikingly repressed in the testing well treated with ECa233 in a concentration-dependent manner after fixing the cells with stabilizing and fixing reagentswhen compared with the numbers of cells in the control group. The results showed that ECa233 potentially decreased the wound closing rate when comparing the width of the wound closing to the absence of any treatment in the control. This is in contrast to the recent study of Singkhorn et al. [33], which demonstrated the effect and underlying molecular mechanism of ECa233 extract on the cell migration of a human keratinocyte cell (HaCaT) using the wound healing assay. It was found that the ability correlating the cell migration of $\mathrm{HaCaT}$ cells was predominantly higher than untreated cells in a concentration- and time-dependent manner. ECa233 induced the cell migration and promoted wound healing in co-ordination with keratinocyte mediating through the activation of FAK, Akt, and MAPK signaling pathway, which supports the role of ECa233 to be used as a further herbal medicine involved with wound repair in clinical trials [33].

Cell invasion is a multistep process of metastasis, which has a crucial role in clinical conditions. Cell adhesion and proteolytic degradation are the first steps to support cell migration to the basement membrane to reach the circulatory system and re-migrate inside the boundary of the secondary distant organs [34]. Hence, the interruption of any steps during tumor metastasis could result in metastatic therapy. The present study is a first-line demonstration that ECa233 at non-toxic dosage can exert effects on tumor cells through the inhibition of migration through the basement membrane (matrigel). The invasive phenomenon of tumor metastatic cells depends on several factors affecting the extracellular matrix degradation. Therefore, the ability to stop aggressive tumor cells at the cellular level is considered as a therapeutic intervention. These results collectively support the highly effective inhibitory effects of ECa233 on cancer cell invasion through the matrigel invasion chambers. MMP-9 is a valuable target in cancer therapy for the development of MMP-9 inhibitors in clinical trials. Matrix metalloproteinase 9 is a zinc-dependent endopeptidase enzyme that degrades the extracellular matrix and collagen fiber. It is an invasive enzyme that acts as a driving factor in cancer progression and metastasis [35]. MMP-9 has been extensively studied in pre-clinical and clinical trials. However, targeting MMP-9 inhibitors has been largely unsuccessful in clinical trials, yet they remain valuable desirable therapeutic targets based on clinical research. Increasing the expression of MMP-9 is strongly correlated to cell proliferation and an increase in tumor size in patients. Finally, it has been demonstrated that MMP-9 is linked to the angiogenesis process by degrading the basement membrane, allowing endothelial cell metastasis invasion into the capillary system, and it is widely identified that metastasis and angiogenesis are closely related [36,37]. Therefore, MMP-9 is an attractive target for therapy. The results revealed that ECa233 strongly inhibits MMP-9 secretion and MMP-9 proteolytic activity. These findings support the results which were obtained from the matrigel invasion assay performed in this study, in which it was found that ECa233 inhibited SW-620 colorectal cancer cell invasion in a dose-dependent manner. Taken together with the results from the ELISA assay, it is suggested that ECa233 inhibits the invasion of cancer by reducing the secretion of MMP-9 protein activity. Therefore, in the multiple synergistic effects of 5-FU and ECa233, it is presumed that ECa233 can improve the efficacy of 5-FU involving induced cancer cell apoptosis by activating intrinsic apoptotic pathways and the arrest of the cell cycle by altering the expression of cell cycle proteins. However, the effects of ECa233 must be investigated in further studies. In addition, the ability of colorectal cancer cells to form and generate colonies as well as to migrate and invade was repressed. Furthermore, MMP-9 protein serum was suppressed after being treated with lower 
http://wjst.wu.ac.th

concentrations of ECa233. Though 1 possible mechanism of the anti-invasive activity of ECa233 was elucidated, the specific molecular mechanism of ECa233 should be clarified to confirm the anti-invasive activity and anti-cancer effects on tumor cells. Interestingly, non-toxic concentrations of ECa233 have few side effects on normal cells. Therefore, as ECa233 has minimal or no complications resulting from its anti-cancer activity, it should be further developed as an anti-metastatic agent in the future. These results are the theoretical foundation for the possibility to develop ECa233 as a potentiation agent for the treatment of colorectal cancer metastasis.

\section{Conclusions}

The combination of ECa233 and 5-FU is strongly effective in inhibiting colorectal cancer cells. ECa233 has the proven ability to improve the cell-cycle specific properties of 5-FU. Therefore, the combination of 5-FU and ECa233 may be recommended for clinical trial studies. Characterization of the inhibitory effects of ECa233 was revealed as the reductive expression of MMP-9 invasive protein. Inhibition of MMP-9 protein expression and reducing invasion migrability during the processes of metastasis have received considerable attention regarding their use in the treatment of invasive cancer and potentially highly malignant cancer. However, it must be investigated to evaluate the efficacy of ECa233 combined with the established 5-FU in animal tumor models and clinical trials as well as to explore its potency and determine the co-inhibitory effects on genes and proteins involved with cellular evading of cell cycle arrest, as well as to investigate its effects on the proteins and co-expression level receptors associated with migrative ability, which will support migration capacity in future studies.

\section{Acknowledgments}

This work was fully supported by the Research Grant of Burapha University through the National Research Council of Thailand (Grant number, 18/2559 and Grant number, 169/2561) for Suwisit Manmuan. This work was also partially supported by the Research Grant of the Faculty of Pharmaceutical Sciences, Burapha University for the Senior project in Pharmaceutical Sciences. We would also like to thank the Faculty of Pharmaceutical Sciences, Burapha University for providing the laboratory facilities.

\section{References}

[1] B Siripongpreeda, C Mahidol, N Dusitanond, T Sriprayoon, B Muyphuag, T Sricharunrat, N Teerayatanakul, W Chaiwong, W Worasawate, P Sattayarungsee, J Sangthongdee, J Prarom, G Sornsamdang, K Soonklang, K Wittayasak and CU Auewarakul. High prevalence of advanced colorectal neoplasia in the Thai population: a prospective screening colonoscopy of 1,404 cases. BMC Gastroenterol. 2016; 16,101.

[2] Y Zhang, Z Chen and J Li. The current status of treatment for colorectal cancer in China: A systematic review. Medicine (Baltimore) 2017; 96, e8242.

[3] CM Lund, D Nielsen, C Dehlendorff, AB Christiansen, F Rønholt, JS Johansen and KK Vistisen. Efficacy and toxicity of adjuvant chemotherapy in elderly patients with colorectal cancer: The ACCORE study. ESMO Open 2016; 1, e000087.

[4] G Masi, L Marcucci, F Loupakis, E Cerri, C Barbara, S Bursi, G Allegrini, IM Brunetti, R Murr, S Ricci, S Cupini, M Andreuccetti and A Falcone. First-line 5-fluorouracil/folinic acid, oxaliplatin and irinotecan (FOLFOXIRI) does not impair the feasibility and the activity of second line treatments in metastatic colorectal cancer. Ann Oncol. 2006; 17, 1249-54.

[5] M Kotake, T Aoyama, Y Munemoto, K Doden, M Kataoka, K Kobayashi, G Nishimura, H Fujita, K Nakamura, A Takehara, C Tanaka, J Sakamoto, N Nagata, K Oba and K Kondo. Multicenter phase II study of infusional 5-fluorouracil (5-FU), leucovorin, and oxaliplatin, plus biweekly cetuximab as first-line treatment in patients with metastatic colorectal cancer (CELINE trial). Oncol. Lett. 2017; 13, 747-53. 
[6] S Giacchetti, B Perpoint, R Zidani, N Le Bail, R Faggiuolo, C Focan, P Chollet, JF Llory, Y Letourneau, B Coudert, F Bertheaut-Cvitkovic, D Larregain-Fournier, AL Rol, S Walter, R Adam, JL Misset and F Lévi. Phase III multicenter randomized trial of oxaliplatin added to chronomodulated fluorouracil-leucovorin as first-line treatment of metastatic colorectal cancer. $J$ Clin. Oncol. 2000; 18, 136-47.

[7] XB Liang, SH Hou, YP Li, LC Wang, X Zhang and J Yang. Irinotecan or oxaliplatin combined with 5-fluorouracil and leucovorin as first-line therapy for advanced colorectal cancer: A meta-analysis. Chin. Med. J. (Engl). 2010; 123, 3314-8.

[8] N Saijo. Present status and problems on molecular targeted therapy of cancer. Cancer Res. Treat. 2012; 44, 1-10.

[9] JB Fitzgerald, B Schoeberl, UB Nielsen and PK Sorger. Systems biology and combination therapy in the quest for clinical efficacy. Nat. Chem. Biol. 2006; 2, 458-66.

[10] R Bayat Mokhtari, TS Homayouni, N Baluch, E Morgatskaya, S Kumar, B Das and H Yeger. Combination therapy in combating cancer. Oncotarget 2017; 8, 38022-43.

[11] MV Blagosklonny. Overcoming limitations of natural anticancer drugs by combining with artificial agents. Trends. Pharmacol. Sci. 2005; 26, 77-81.

[12] EC Saputra, L Huang, Y Chen and L Tucker-Kellogg. Combination therapy and the evolution of resistance: The theoretical merits of synergism and antagonism in cancer. Cancer Res. 2018; 78, 2419-31.

[13] VK Ngan, K Bellman, BT Hill, L Wilson and MA Jordan. Mechanism of mitotic block and inhibition of cell proliferation by the semisynthetic Vinca alkaloids vinorelbine and its newer derivative vinflunine. Mol. Pharmacol. 2001; 60, 225-32.

[14] H Ishikawa, DA Colby, S Seto, P Va, A Tam, H Kakei, TJ Rayl, I Hwang and DL Boger. Total synthesis of vinblastine, vincristine, related natural products, and key structural analogues. J. Am. Chem. Soc. 2009; 131, 4904-16.

[15] O Wanakhachornkrai, V Pongrakhananon, P Chunhacha, A Wanasuntronwong, A Vattanajun, B Tantisira, P Chanvorachote and MH Tantisira. Neuritogenic effect of standardized extract of Centella asiatica ECa233 on human neuroblastoma cells. BMC Complement Altern. Med. 2013; 13, 204.

[16] J Somboonwong, M Kankaisre, B Tantisira and MH Tantisira. Wound healing activities of different extracts of Centella asiatica in incision and burn wound models: an experimental animal study. BMC Complement Altern. Med. 2012; 12, 103.

[17] A Wanasuntronwong, $\mathrm{MH}$ Tantisira, $\mathrm{B}$ Tantisira and $\mathrm{H}$ Watanabe. Anxiolytic effects of standardized extract of Centella asiatica (ECa 233) after chronic immobilization stress in mice. $J$. Ethnopharmacol. 2012; 143, 579-85.

[18] S Doknark, S Mingmalairak, A Vattanajun, B Tantisira and MH Tantisira. Study of ameliorating effects of ethanolic extract of Centella asiatica on learning and memory deficit in animal models. $J$. Med. Assoc. Thai. 2014; 97, S68-76.

[19] A Wanasuntronwong, O Wanakhachornkrai, P Phongphanphanee, T Isa, B Tantisira and MH Tantisira. Modulation of neuronal activity on intercalated neurons of amygdala might underlie anxiolytic activity of a standardized extract of centella asiatica ECa233. Evid. Based Complement Alternat. Med. 2018; 2018, 3853147.

[20] N Teerapattarakan, H Benya-Aphikul, R Tansawat, O Wanakhachornkrai, MH Tantisira and R Rodsiri. Neuroprotective effect of a standardized extract of Centella asiatica ECa233 in rotenoneinduced parkinsonism rats. Phytomedicine 2018; 44, 65-73.

[21] S Chivapat, P Chavalittumrong and $\mathrm{MH}$ Tantisira. Acute and sub-chronic toxicity studies of a standardized extract of Centella asiatica ECa233. Thai. J. Pharm. Sci. 2011; 35, 55-64.

[22] P Hengjumrut, T Anukunwithaya, MH Tantisira, B Tantisira and P Khemawoot. Comparative pharmacokinetics between madecassoside and asiaticoside presented in a standardised extract of Centella asiatica, ECa 233 and their respective pure compound given separately in rats. Xenobiotica 2018; 48, 18-27. 
http://wjst.wu.ac.th

[23] T Anukunwithaya, MH Tantisira, B Tantisira, P Khemawoot. Pharmacokinetics of a standardized extract of centella asiatica ECa 233 in rats. Planta Med. 2017; 83, 710-7.

[24] P Songvut, P Chariyavilaskul, MH Tantisira and P Khemawoot. Safety and pharmacokinetics of standardized extract of centella asiatica (ECa 233) capsules in healthy Thai volunteers: A phase 1 clinical study. Planta Med. 2019; 85, 483-90.

[25] TL Riss, RA Moravec, AL Niles, S Duellman, HA Benink, TJ Worzella, L Minor, S Markossian, GS Sittampalam, A Grossman, K Brimacombe, M Arkin, D Auld, CP Austin, J Baell, JMM Caaveiro, TDY Chung, NP Coussens, JL Dahlin, V Devanaryan, TL Foley, M Glicksman, MD Hall, JV Haas, SRJ Hoare, J Inglese, PW Iversen, SD Kahl, SC Kales, S Kirshner, M Lal-Nag, Z Li, J McGee, O McManus, T Riss, P Saradjian, OJ Trask, JR Weidner, MJ Wildey, M Xia and X Xu. Cell viability assays. In: Assay Guidance Manual. Bethesda (MD), 2004.

[26] TC Chou. Drug combination studies and their synergy quantification using the Chou-Talalay method. Cancer Res. 2010; 70, 440-6.

[27] C Filgueiras Mde, A Morrot, PM Soares, ML Costa and C Mermelstein. Effects of 5-fluorouracil in nuclear and cellular morphology, proliferation, cell cycle, apoptosis, cytoskeletal and caveolar distribution in primary cultures of smooth muscle cells. PLoS One 2013; 8, e63177.

[28] YS Jung, Y Qian and X Chen. Examination of the expanding pathways for the regulation of p21 expression and activity. Cell Signal 2010; 22, 1003-12.

[29] P Bunpo, K Kataoka, H Arimochi, H Nakayama, T Kuwahara, Y Ohnishi and U Vinitketkumnuen. Centella asiatica extract induces cell cycle arrest in Caco-2 human colon cancer cells. Chiang Mai Med. Bull. 2005; 44, 21-28.

[30] Y Hao, J Huang, Y Ma, W Chen, Q Fan, X Sun, M Shao and H Cai. Asiatic acid inhibits proliferation, migration and induces apoptosis by regulating Pdcd4 via the PI3K/ Akt/ mTOR/ p70S6K signaling pathway in human colon carcinoma cells. Oncol. Lett. 2018; 15, 8223-30.

[31] J He, L Pei, H Jiang, W Yang, J Chen and H Liang. Chemoresistance of colorectal cancer to 5fluorouracil is associated with silencing of the BNIP3 gene through aberrant methylation. J. Cancer 2017; 8, 1187-96.

[32] M Shakibaei, P Kraehe, B Popper, P Shayan, A Goel and C Buhrmann. Curcumin potentiates antitumor activity of 5-fluorouracil in a $3 \mathrm{D}$ alginate tumor microenvironment of colorectal cancer. BMC Cancer 2015; 15, 250.

[33] S Singkhorn, MH Tantisira, S Tanasawet, P Hutamekalin, T Wongtawatchai and W Sukketsiri. Induction of keratinocyte migration by ECa 233 is mediated through FAK/Akt, ERK, and p38 MAPK signaling. Phytother. Res. 2018; 32, 1397-403.

[34] P Friedl and S Alexander. Cancer invasion and the microenvironment: Plasticity and reciprocity. Cell 2011; 147, 992-1009.

[35] C Gialeli, AD Theocharis and NK Karamanos. Roles of matrix metalloproteinases in cancer progression and their pharmacological targeting. FEBS J. 2011; 278, 16-27.

[36] SO Yoon, SJ Park, CH Yun and AS Chung. Roles of matrix metalloproteinases in tumor metastasis and angiogenesis. J. Biochem. Mol. Biol. 2003; 36, 128-37.

[37] S Damery, L Nichols, R Holder, ST Ward, S Warmington, S Wilson, MJ Wakelam, J James and T Ismail. Assessing the value of matrix metalloproteinase 9 (MMP9) in improving the appropriateness of referrals for colorectal cancer. Br. J. Cancer 2013; 108, 1149-56. 